\title{
N-JILS
}

Nusantara

Journal of Information and Library Studies

Journal homepage: ojs.uninus.ac.id/index.php/JILS

\section{Pengukuran Kualitas Layanan Perpustakaan: Studi Pada Perpustakaan STIE Ekuitas Bandung}

\section{Measurement Of Library Service Quality: Study At The STIE Ekuitas Library In Bandung}

\author{
Asep Saeful Rohman \\ Program Studi Perpustakaan dan Sains Informasi, Universitas Padjadjaran \\ e-mail: asep.saeful@unpad.ac.id
}

\begin{tabular}{ll}
\hline ARTICLE INFO & ABSTRACT \\
\hline Article history & This study aims to determine the extent of the quality of \\
Received [May, 2020] & library services STIE Ekuitas Bandung. Service quality is \\
Revised [June, 2020] & seen based on the comparison between the services \\
Accepted [June, 2020] & received by users and their expectations of library services. \\
Available Online [June, 2020] & The scope of the research is on aspects of the attitude of \\
officers (librarians) in serving (Affect of Service), access to & information (Information Control), and the library as a \\
place. The method used is a survey with a quantitative \\
approach. Data collection was carried out using \\
questionnaires, interviews, observations, and literature \\
studies. The population of this research is the library \\
members totaling 1594 students. By using non-probability \\
sampling techniques and Yamane sample calculation \\
formula obtained a number of 99 respondents. Data \\
analysis uses the LibQual TM Model by measuring the gaps \\
of services received and services expected by users. Based \\
on the results of the study note that the average service \\
quality is at the tolerance limit. This means that the STIE \\
Ekuitas Bandung Library service received by users is \\
considered quite good by users, which is above the \\
minimum expected number. Another finding is that the \\
library is still not maximal in providing superior services, \\
namely services that are in accordance with the maximum \\
expectations desired by the user.
\end{tabular}


Kata Kunci : kualitas layanan perpustakaan, libqual ${ }^{\mathrm{TM}}$, STIE Ekuitas Bandung

\begin{abstract}
ABSTRAK
Penelitian ini bertujuan untuk mengetahui sejauhmana kualitas layanan perpustakaan STIE Ekuitas Bandung. Kualitas layanan dilihat berdasarkan perbandingan antara layanan yang diterima oleh pengguna/pemustaka dan harapan mereka terhadap layanan perpustakaan. Ruang lingkup penelitian yakni pada aspek sikap pustakawan (petugas perpustakaan) dalam melayani (Affect of Service), akses terhadap informasi (Information Control), dan perpustakaan sebagai sebuah tempat yang terdiri dari sarana dan prasarana yang ada (Library as Place). Metode yang digunakan adalah survey dengan pendekatan kuantitatif. Pengumpulan data dilakukan menggunakan kuesioner, wawancara, observasi, dan studi pustaka. Populasi penelitian ini adalah anggota perpustakaan sebanyak 1594 mahasiswa STIE Ekuitas Bandung. Dengan menggunakan teknik non probability sampling dan rumus penghitungan sampel Yamane diperoleh sejumlah 99 responden. Analisa data menggunakan Model LibQual ${ }^{\mathrm{TM}}$ yakni dengan mengukur kesenjangan (gap) antara layanan yang diterima dengan layanan yang diharapkan pengguna/pemustaka. Berdasarkan hasil penelitian diketahui bahwa rata-rata kualitas layanan perpustakaan STIE Ekuitas Bandung berada pada area batas toleransi (zone of tolerance). Artinya bahwa layanan Perpustakaan STIE Ekuitas Bandung yang diterima sudah dinilai cukup baik oleh pengguna, yakni diatas angka harapan minimum. Temuan lain bahwa Perpustakaan STIE Ekuitas Bandung, hingga saat penelitian ini dilakukan, masih belum maksimal dalam memberikan layanan yang unggul (superior) kepada pengguna/ pemustakanya, yaitu layanan perpustakaan yang sesuai dengan harapan maksimum yang diinginkan oleh pengguna/ pemustaka.
\end{abstract}

(C) 2020 NJILS. All rights reserved.

\section{A. PENDAHULUAN}

Perpustakaan merupakan sarana belajar bagi masyarakat dengan menyediakan berbagai sumber informasi dan pengetahuan. Tujuan penyelenggaraan perpustakaan sebagai sarana dan sumber belajar terutama dalam rangka meningkatkan kecerdasan dan memenuhi kebutuhan informasi bagi masyarakat. Perpustakaan umumnya dikelola oleh tenaga perpustakaan dan pustakawan. Pengelola bekerja dan berperan penting dalam melayani dan memenuhi permintaan informasi penggunanya (pengguna). Keberadaan perpustakaan tentu sangat berguna bagi semua pihak, karena perpustakaan menyediakan berbagai sumber 
informasi yang sesuai dengan kebutuhan pengguna. Perpustakaan juga menjadi tempat belajar dan berkegiatan bagi masyarakat penggunanya. Ia menjadi ruang publik paling ideal bagi pengembangan kapasitas dan kualitas diri khususnya dan masyarakat pada umumnya.

Di lingkungan perguruan tinggi, perpustakaan berada dalam posisi yang ideal. Ia berfungsi sebagai pusat pengembangan ilmu pengetahuan dan teknologi. Perpustakaan menjadi tempat dimana interaksi antara fungsi pendidikan, riset, dan pusat komunikasi gagasan diantara sivitas akademika dan masyarakat dapat terjadi secara efektif dan intensif. Perpustakaan perguruan tinggi berperan penting dalam mendukung Tri Dharma Perguruan Tinggi yaitu pendidikan, penelitian dan pengabdian pada masyarakat. Tidak salah jika perpustakaan sering disebut sebagai “jantungnya perguruan tinggi”. Hal ini berarti bahwa perpustakaan memiliki peranan yang amat penting dalam dunia pendidikan. Jika jantungnya lemah, tubuh lainnya juga akan menjadi lemah, akan berpengaruh pula terhadap institusi tempat perpustakaan bernaung. Sebaliknya, jika jantungnya baik, akan membuat baik pula tubuhnya, yakni penyelenggaraan perguruan tinggi tersebut secara keseluruhan.

Dalam penyelenggaraan perpustakaan, semakin baik kualitas layanannya secara otomatis akan meningkatkan pula citra dan kepercayaan penggunanya. Dalam melaksanakan kewajibannya, perpustakaan perlu memperhatikan berbagai seperti ketersediaan koleksi hingga fasilitas sarana dan prasarananya. Termasuk yang paling penting adalah bagaimana kesiapan dan kemampuan staf dalam melayani penggunanya. Sebagai lembaga layanan, perpustakaan perguruan tinggi diharapkan mampu memberikan layanan yang terbaik dan berkualitas bagi pengguna dalam memenuhi kebutuhan informasinya. Oleh karena itu, kepuasan pengguna menjadi tolok ukur dalam keberhasilan layanan yang diberikan oleh jasa pengelola perpustakaan. Tjiptono (2008) menyatakan bahwa pada dasarnya kualitas layanan itu berfokus pada upaya pemenuhan kebutuhan dan keinginan pelanggan serta ketepatan penyampaian untuk mengimbangi harapannya. Upaya untuk memenuhi ekspektasi dan mewujudkan kepuasan pengguna, pihak perpustakaan perlu menyusun program peningkatan kualitas pelayanan untuk diterapkan secara lebih tepat dan terintegrasi.

Berdiri sejak tahun 2003, Perpustakaan STIE Ekuitas Bandung dikelola oleh seorang kepala perpustakaan dan tiga orang staf perpustakaan. Berdasarkan pengamatan awal bahwa perpustakaan ini telah menggunakan sistem otomasi. Dalam perkembangannya, pihak pengelola perpustakaan terus berupaya meningkatkan kualitas pelayanan dengan lebih menunjukkan sikap yang baik serta kemampuan untuk dapat memberikan pelayanan yang baik. Jumlah koleksi di Perpustakaan STIE Ekuitas Bandung hingga tahun 2019 lalu 
berjumlah 3279 judul buku, 430 judul jurnal, 5297 judul skripsi, 561 judul tugas akhir, 1536 judul laporan praktik kerja lapangan, serta koleksi referensi lainnya sejumlah 1270 judul. Hingga penelitian ini dilakukan, jumlah koleksi perpustakaan terus ditingkatkan baik melalui pengadaan dengan metode pembelian maupun menerima sumbangan dari berbagai pihak. Pengelolaan koleksi dan layanan perpustakaan dilakukan secara otomatis dengan menggunakan software SUTEKI. Fasilitas gedung dan ruangan yang digunakan untuk perpustakaan nampak masih terbatas sehingga menjadi kendala tersendiri dalam menambah jumlah rak penyimpanan koleksi maupun untuk layanan ruang baca dan diskusi. Berdasarkan hasil wawancara, bahwa sejauh ini pihak pengelola Perpustakaan STIE Ekuitas Bandung belum mengetahui secara pasti tentang sejauhmana penilaian pengguna terhadap layanan yang mereka selenggarakan.

Berdasarkan paparan secara singkat di atas, maka penelitian ini berupaya untuk dapat mengetahui sejauhmana kualitas layanan Perpustakaan STIE Ekuitas Bandung. Secara lebih spesifik penelitian ini berupaya mengetahui bagaimana persepsi dan harapan pengguna tentang kemampuan dan sikap staf dalam melayani mereka (Affect of Service), ketersediaan informasi dan kemudahan akses informasi (Information Control), serta bagaimana pandangan pengguna tentang Perpustakaan STIE Ekuitas Bandung sebagai sebuah tempat/ruang serta fasilitas layanan.

\section{B. TINJAUAN PUSTAKA}

Perpustakaan dikatakan bergerak ketika adanya aktivitas didalamnya antara pustakawan (staf perpustakaan) dengan pengguna (pengguna perpustakaan). Dalam konsep layanan berarti ketika ada praktik jasa yang diberikan. Layanan perpustakaan yaitu suatu kegiatan yang diberikan petugas (staf) perpustakaan kepada pengguna dengan tujuan untuk memenuhi kebutuhan informasinya. Menurut Sutarno (2005) bahwa layanan perpustakaan yang efektif adalah yang dapat memenuhi keinginan penggunanya dalam hal penyediaan informasi yang sesuai dengan keinginan pemakai; waktu layanan yang tepat, leluasa, memadai dan tidak terlalu mengikat, termasuk kesempatan sore dan malam untuk kelompok pengguna tertentu; kebebasan, tata cara dan akses informasi, tidak kaku dengan pengawasan longgar, tidak terlalu ketat, tertib, kondusif dan simpatik; suasana yang menyenangkan, aman, tenang, tenteram, jauh dari kegaduhan dan kebisingan; sikap dan prilaku petugas yang penuh perhatian, ramah, santun, bersifat membimbing, memandu, dan menguasai masalah; tata tertib yang sederhana, mudah dipahami, mudah diikuti dan dilaksanakan; adanya fasilitas dan kemudahan yang lain seperti panduan, petunjuk, informasi singkat atau lainnya; 
menimbulkan kesan yang baik, menyenangkan dan memuaskan sehingga pengguna ingin selalu kembali lagi; serta berorientasi kepada pelanggan atau konsumen dan bersifat mandiri.

Layanan yang dapat memenuhi kebutuhan penggunanya adalah layanan yang efektif. Layanan tersebut dapat dikatakan efektif apabila penyediaan informasi sesuai, waktu yang leluasa, kebebasan dalam memanfaatkan layanan, suasana yang menyenangkan, sikap dan prilaku petugas perpustakaan yang penuh perhatian, tata tertib yang sesuai, adanya fasilitas dan kemudahan lain, menimbulkan kesan yang baik dan senantiasa berorientasi kepada pelanggan. Jasa layanan apapun dapat diukur kualitasnya. Termasuk layanan jasa perpustakaan. Salah satu model yang populer digunakan untuk mengukur layanan perpustakaan adalah model LibQual+TM.

Menurut Fatmawati (2013) bahwa LibQual ${ }^{\mathrm{TM}}$ is a suite of service that libraries use to solicit, track, understand, and act upon users opinions of service quality. Artinya bahwa LibQual ${ }^{\mathrm{TM}}$ merupakan sebuah paket instrumen untuk dapat melihat dan memahami layanan yang diselenggarakan oleh perpustakaan serta mengetahui sejauhmana pendapat pengguna terhadap kualitas layanan perpustakaan. Penelitian tentang kualitas layanan memperhatikan 3 (tiga) dimensi model LibQual yakni kemampuan dan sikap staf dalam melayani pengguna (Affect of Service), informasi dan kemudahan akses informasi (Information Control), dan kondisi gedung/ ruangan perpustakaan (Library as Place).

LibQual+TM dapat digunakan untuk memecahkan masalah, melihat mana yang sudah benar atau yang salah dari perpustakaan, dengan tujuan utama untuk memperbaiki layanan kepada pengguna. Metode ini digunakan dengan cara mengukur kualitas layanan perpustakaan berdasarkan persepsi dan harapan pengguna. Persepsi (Perceived) merupakan tingkat layanan yang kenyataannya diterima/dialami pengguna. Sementara harapan dalam konsep LibQual+TM dibagi menjadi harapan minimum (minimum expectation) dan harapan ideal (desired). Harapan minimum (minimum expectation), yaitu serendah-rendahnya tingkat layanan minimum yang dapat diterima (acceptable) atau yang masih dapat ditolerir. Sementara harapan ideal (desired) merupakan tingkat layanan perpustakaan yang secara pribadi sebenarnya diinginkan atau diidealkan. Oleh karena itu, harapan ideal pengguna tentu nilainya akan lebih besar daripada harapan minimun pengguna.

Model LibQual+TM mengukur kualitas layanan di perpustakaan berdasarkan persepsi, harapan minimum, dan harapan ideal penggunanya. Dimensi kualitas layanan perpustakaan dan indikator dengan menggunakan model LibQual+ ${ }^{\mathrm{TM}}$ yakni sebagai berikut. Pertama, kemampuan dan sikap pustakawan dalam melayani (Service Affect - SA) yaitu kemampuan, sikap dan mentalitas pustakawan dalam melayani pengguna. Kualitas layanan perpustakaan 
akan menjadi semakin baik apabila pustakawan mempunyai kemampuan sebagai perantara/penengah (intermediary) dan penghubung antara perpustakaan dengan pengguna (liaison librarian) secara profesional. Indikator dari Service Affect (SA) meliputi : a). Empati/kepedulian (Empathy) : threating custorner as individuals. Memberikan perhatian yang bersifat individual atau pribadi kepada pengguna dan berupaya untuk memahami keinginan/kebutuhannya yang meliputi kemudahan dalam melakukan hubungan komunikasi yang baik; b). Ketanggapan (Responsiveness): being willing to help. Kemauan/kesediaan para pustakawan untuk membantu dan memberikan layanan dengan tanggap dan cepat (responsif) kepada pengguna; c). Jaminan/kepastian (Assurance): inspiring truth and confidence. Mencakup kearnanan, kesopanan dan keramahan, sifat dapat dipercaya yang dimiliki para pustakawan, adanya sikap ramah, sopan, bersahabat, bebas dari bahaya, resiko atau keragu-raguan serta pengetahuan yang dimiliki pustakawan. Selain itu, juga kemampuan pustakawan dalam melakukan tugas pokok dan fungsi (tupoksi) di perpustakaan dalam melayani pengguna; d). Reliabilitas/keandalan (Reliability) : delivering on promise. Maksudnya yaitu suatu kemampuan untuk memberikan layanan perpustakaan yang dijanjikan dengan akurat, tepat waktu, konsisten, segera, memuaskan, dan terpercaya kepada pengguna.

Kedua, fasilitas dan suasana ruang perpustakaan (Library as Place - LP), yaitu perpustakaan dianggap sebagai sebuah tempat yang mempunyai kemampuan untuk menannpilkan sesuatu secara nyata berupa fasilitas (physical facilities), bagaimana perpustakaan dalam memanfaatkan ruang, peralatan/perabotan (equipment), ketersediaan sarana peralatan komunikasi dan petugas (personnel and communication materials), maupun sebagai symbol dan tempat perlindungan. Konsep library as place digunakan untuk menilai kemampuan perpustakaan dalam memenuhi harapan pengguna dalam penyediaan berbagai fasilitas di perpustakaan. Aspek dalam library as place adalah: a). berwujud/ada bukti fisik (Tangibles): representing the service phisicaly. Fasilitas fisik dan perlengkapan di perpustakaan, gedung yang bagus dan ber-AC, tersedia fasilitas sarana penelusuran (OPAC), sarana komunikasi (telepon/intercom), tempat parkir yang luas, sarana ibadah, bookstore, peralatan computer yang canggih, jurnal ilmiah (nasional dan intemasional), e-joumals, online databases, serta penampilan, cara berkomunikasi, seragam pustakawan yang menarik; b). ruang yang bermanfaat Utilitarian Space), yaitu adanya ruangan di perpustakaan yang bisa dimanfaatkan untuk diskusi dan belajar bagi segenap civitas akademik; c). berbagai makna (Symbol) yang nyata, meliputi peralatan, fasilitas fisik, dan peralatan komunikasi yang disediakan di perpustakaan; d). tempat belajar yang nyaman (Refuse), meliputi penyediaan ruang belajar yang merangsang kreativitas dan imajinasi, tempat yang kondusif 
untuk bertumbuh kembangnya pikiran.

Ketiga, sarana dan akses informasi (Information Control - IC), yaitu suatu konsep yang membuat pengguna dapat melakukan sendiri apa yang diinginkannya dalam mencari dan penggunaan informasi tanpa bantuan pustakawan. Hal ini menyangkut aspek sarana informasi yakni : a). kemudahan akses (Ease of Navigation), bahwa pengguna dapat melakukan sendiri apa yang diinginkannya dalam mencari informasi tanpa bantuan pustakawan; b). kenyamanan individu pengguna (Convenience), mencakup kenyamanan waktu yang dibutuhkan dalam mendapatkan informasi dan ketiadaan hambatan dalam mengakses informasi pada saat dibutuhkan; c). peralatan yang modern (Modern Equipment), meliputi berbagai fasilitas perpustakaan yang mutakhir dan sesuai kebutuhan pengguna; d). kepercayaan diri (Self Reliance), bahwa pengguna mempunyai keyakinan dapat menggunakan sarana akses dan berbagai petunjuk penelusuran informasi di perpustakaan.

Akses informasi (Informatian Access - IA), berkaitan dengan ketersediaan bahan perpustakaan yang memadai, kekuatan bahan perpustakaan yang dimiliki, cakupan isi/ruang lingkup, aktualitas, bimbingan pustakawan, maupun tingkat kecepatan waktu akses informasi di perpustakaan. Pada dimensi akses infonnasi ini meliputi: a). isi/ruang lingkup (Content/Scope) mencakup ketersediaan koleksi yang memadai, kekayaan koleksi jurnal full text maupun sumber informasi lainnya yang dimiliki, serta tersedianya bimbingan pengguna untuk menelusur informasi diperpustakaan. b). kecepatan waktu akses (Timeliness) mencakup kemudahan akses untuk menemukan informasi yang relevan dan akurat. (Fatmawati, 2011)

Penelitian tentang layanan perpustakaan, khususnya tentang pengukuran kualitas layanan maupun kepuasan pengguna/pemustaka telah cukup banyak dilakukan. Termasuk pada perpustakaan-perpustakaan di Indonesia. Idealnya penelitian semacam ini dilakukan oleh penyelenggara perpustakaan dengan Pustakawan sebagai penelitinya. Penelitian yang pernah dilakukan oleh pustakawan dalam meneliti kualitas layanan misalnya yang dilakukan oleh Yulianti (2016). Penelitian lain yang hampir sama, lebih banyak diteliti oleh akademisi (dosen) maupun mahasiswa. Seperti misalnya penelitian yang dilakukan oleh Aliza (2017) dan Nurvia (2016). Beberapa penelitian tersebut berupaya mengukur sejauhmana kualitas perpustakaan yang telah dan sedang diselenggarakan menggunakan Model Libqual ${ }^{\mathrm{TM}}$ sebagai instrumen alat ukurnya. Seperti halnya penelitian tersebut, penelitian ini juga berupaya mengetahui sejauhmana kualitas layanan di perpustakaan. Model Libqual ${ }^{\mathrm{TM}}$ masih cukup relevan digunakan sebagai alat ukur yang terpercaya. Diakui bahwa tidak ada hal baru dalam penggunaan model pengukuran dalam penelitian tentang kualitas layanan perpustakaan ini. 
Namun tentu hasil pengukuran pada tiap perpustakaan akan berbeda satu dengan lainnya.

Model LibQual ${ }^{\mathrm{TM}}$ menilai betapa pentingnya menjaga budaya layanan perpustakaan. Model ini juga dapat membantu perpustakaan agar lebih memahami persepsi dan harapan pengguna terhadap layanan perpustakaan, mengumpulkan dan menafsirkan masukan pengguna secara sistematis dari waktu ke waktu, memberikan penilaian perpustakaan terhadap isi informasi dari rekan lembaga lain sebagai pembanding, mengidentifikasi praktek-praktek terbaik dalam pelayanan perpustakaan, meningkatkan kemampuan analisa staf perpustakaan, serta kemampuan mereka untuk bertindak terhadap data secara obyektif (Fatmawati, 2013).

\section{METODE PENELITIAN}

Penelitian ini mengenai kualitas layanan Perpustakaan STIE Ekuitas ini menggunakan pendekatan kuantitatif dengan metode survey. Peneliti mencari tahu "sejauhmana" kualitas layanan perpustakan berdasarkan harapan dan persepsi pengguna dengan memberikan gambaran yang detail mengenai suatu fakta yang ada dan terjadi. Jumlah populasi pada penelitian ini adalah 1594. Populasi yakni terdiri dari mahasiswa STIE Ekuitas yang berkunjung ke perpustakaan selama tahun akademik 2018-2019. Pengukuran sampel menggunakan teknik non probability sampling. Hasil perhitungan sampel dengan menggunakan rumus Yamane diperoleh ukuran sampel sebanyak 98,50. Jika dibulatkan menjadi sebanyak 99 responden. Penyebaran kuesioner menggunakan teknik accidental sampling dimana peneliti mendapati responden terutama mahasiswa STIE Ekuitas Bandung sebagai pemustaka yang sedang berkunjung ke perpustakaannya. Selain itu, data juga diperoleh dari teknik pengamatan, studi pustaka, dan wawancara tidak terstruktur dengan pengelola perpustakaan. Data yang diperoleh dari penyebaran kuesioner, kemudian diolah menggunakan MS Excel. Analisa data dilakukan dengan menggunakan analisa gap, yakni menghitung skor rata-rata dan membandingkan antara nilai persepsi, harapan minimum, maupun harapan sesungguhnya. Analisa gap dilakukan dimulai dari setiap item pernyataan, dimensi, dan secara keseluruhan sehingga diperoleh ukuran kualitas layanan perpustakaan berdasarkan harapan dan persepsi pemustaka.

Penilaian kualitas layanan perpustakaan menggunakan metode $L i b Q U A L^{\mathrm{TM}}$ diketahui dengan menghitung nilai atau skala skor kesenjangan (gap). Fungsinya untuk membandingkan kualitas layanan perpustakaan apakah belum memenuhi kepuasaan pengguna ataukah sudah menenuhi kepuasan pengguna. Berikut ini merupakan rumus kesenjangan untuk membandingkan atau menghitung nilai kesenjangan atau (score gap): 


\section{AG $($ Adequacy Gap $)=$ Perceived $(\mathrm{P})-\operatorname{Minimum}(\mathrm{M})$ \\ SG $($ Superiority Gap $)=$ Perceived $(\mathrm{P})-$ Desired $(\mathrm{D})$}

Maksud dari skor AG (Adequacy Gap) dan SG (Superiority Gap) pada rumus tersebut dapat dijelaskan sebagai berikut. Adequacy Gap (AG), merupakan nilai selisih yang diperoleh dari persepsi (Perceived) dikurangi harapan minimum (Mininum). Jadi AG itu bernilai positif, yang berarti responden "cukup puas", jika persepsi > harapan minimum (P > HM). Apabila skor SG bernilai positif menunjukkan bahwa layanan yang diberikan telah melebihi harapan pengguna. Dalam kondisi ini pengguna cukup puas terhadap layanan yang diterimanya. Lalu, jika skor SG menunjukkan nilai negatif, maka kualitas layanan berada pada 'zone tolerance', dimana kualitas layanan dinilai cukup baik yakni berada di antara tingkat minimum yang dapat diterima dan tingkat harapan ideal (desired). Jadi persepsi pengguna dikatakan cukup ideal jika berada dalam wilayah "zone of tolerance" ini. Zone of tolerance bisa meningkat maupun menurun, tergantung atribut layanan yang bisa dikendalikan.

Berikutnya nilai Superiority Gap (SG) merupakan nilai selisih yang diperoleh dari persepsi (perceived) dikurangi harapan ideal (desired). Nilai SG bernilai negatif jika persepsi $<$ harapan ideal $(\mathrm{P}<\mathrm{HI})$. Dalam kondisi ini layanan yang diberikan belum memenuhi harapan ideal dari pengguna, sehingga pengguna belum cukup puas terhadap layanan yang diterimanya. Apabila skor AG menunjukkan nilai positif, artinya bahwa layanan yang diberikan sudah ideal dan telah melebihi harapan pengguna. Pengguna sudah puas terhadap layanan yang diterima dan sesuai dengan harapannya. (Fatmawati, 2011).

\section{HASIL DAN PEMBAHASAN}

Perpustakaan Sekolah Tinggi Ilmu Ekonomi (STIE) Ekuitas Bandung sebagai salah satu pusat informasi dan pengetahuan khususnya dalam pengembangan ilmu pengetahuan dalam bidang ekonomi mempunyai peranan penting untuk memenuhi kebutuhan informasi bagi penggunanya terutama sivitas akademikanya. Sesuai dengan tugas dan fungsinya, Perpustakaan STIE Ekuitas Bandung senantiasa berupaya melayani penggunanya dengan memperhatikan mutu layanan, kelengkapan koleksi, kenyamanan, kemudahan dalam memperoleh informasi, serta penerapan teknologi informasi yang mempermudah dalam akses informasi. Secara berkala pihak kampus STIE Ekuitas Bandung senantiasa memberikan dukungan bagi upaya peningkatan kualitas layanan untuk memenuhi harapan bagi pengguna perpustakaan yaitu mahasiswa dan dosen, termasuk masyarakat luas. 
Berdasarkan hasil penelitian diperoleh data yang kemudian dianalisa dengan menjumlahkan semua skor layanan yang dipersepsikan, harapan minimum, dan harapan maksimum (harapan sesungguhnya). Skor diperoleh dari nilai rata-rata layanan yang diberikan, harapan minimum, dan harapan maksimum dari semua butir pernyataan. Berikut ini merupakan hasil nilai rata-rata keseluruhan dari ketiga skor kualitas layanan serta perolehan skor AG dan SG :

Tabel 1 Nilai Rata-Rata Keseluruhan Kualitas Layanan Perpustakaan STIE Ekuitas

\begin{tabular}{|c|c|c|c|c|c|}
\hline \multirow{2}{*}{$\begin{array}{c}\text { Rata-Rata } \\
\text { Keseluruhan }\end{array}$} & $\begin{array}{c}\text { Harapan } \\
\text { Minimum }\end{array}$ & $\begin{array}{c}\text { Harapan } \\
\text { Maksimum }\end{array}$ & $\begin{array}{c}\text { Layanan } \\
\text { yang } \\
\text { Dipersepsikan }\end{array}$ & AG & SG \\
\cline { 2 - 6 } & 5,94 & 7,52 & 6,63 & 0,69 & $-0,89$ \\
\hline
\end{tabular}

Sumber : Hasil Pengolahan Data Penelitian, 2019

Hasil perhitungan pada tabel diatas menunjukkan bahwa nilai rata-rata tertinggi adalah harapan maksimum atau harapan yang diinginkan (desired) yaitu 7,52. Kemudian nilai rata-rata layanan yang dipersepsikan adalah 6,63. Dan nilai rata-rata harapan minimum yaitu 5,94. Diketahui bahwa nilai rata- rata harapan minimum lebih kecil dari nilai rata-rata harapan maksimum dan layanan yang diberikan. Sehingga nilai kesenjangan SG keseluruhan adalah $-0,89$, dan nilai AG seluruhnya adalah 0,69.

Berdasarkan nilai AG dapat disimpulkan bahwa kualitas layanan perpustakaan di STIE Ekuitas Bandung sudah memenuhi harapan minimum pengguna. Hal ini berarti pengguna merasa cukup puas dengan layanan perpustakaan. Sementara nilai SG menunjukkan nilai negatif, artinya perpustakaan belum mampu memenuhi kepuasan optimal dari pengguna. Dapat disimpulkan bahwa persepsi (layanan yang diterima pengguna) berada pada batas toleransi (zone of tolerance), dimana kualitas layanan masih terbilang cukup baik atau pengguna merasa cukup puas dengan layanan perpustakaan yang mereka peroleh.

Kualitas layanan perpustakaan merupakan faktor yang sangat penting untuk mencapai kepuasan pengguna. Oleh karena itu, kepuasan pengguna akan terwujud apabila kualitas layanan perpustakaan yang diberikan benar-benar memenuhi kebutuhan dan harapan bagi pengguna. Namun sebaliknya, apabila layanan yang diberikan perpustakaan menimbulkan ketidakpuasan pengguna atau belum memenuhi kebutuhan dan harapan pengguna, maka layanan dinilai masih belum atau bahkan tidak berkualitas. Pengguna adalah pelanggan 
perpustakaan, maka baik atau tidaknya kualitas layanan suatu perpustakaan amat ditentukan oleh pengguna.

Kepuasan yang dirasakan (desired) pengguna merupakan pencapaian yang luar biasa bagi pelayanan suatu perpustakaan. Namun, belum tentu pengelolaan perpustakaan memiliki keunggulan dan pastinya selalu memiliki kekurangan. Menurut Wijaya (2018) bahwa penilaian kualitas yang baik bukanlah diukur dari sudut pandang atau persepsi pihak penyedia jasa, melainkan berdasarkan sudut pandang atau persepsi pelanggan.

Analisis berdasarkan dimensi kualitas layanan di Perpustakaan STIE Ekuitas Bandung dengan menggunakan indikator pengukuran berdasarkan model kualitas layanan perpustakan LibQual+ ${ }^{\mathrm{TM}}$ terdiri dari tiga dimensi. Analisis tiap dimensi kualitas layanan perpustakaan yakni : a). affect of service, penilaian terhadap kemampuan dan sikap pustakawan maupun waktu ketepatan pustakawan dalam melayani pengguna di perpustakaan. Dalam penelitian ini mencakup 6 poin pernyataan; b). information control, penilaian terhadap ketersediaan, pemenuhan, hingga penataan koleksi, automasi dan waktu layanan sirkulasi, serta penilaian terhadap layanan koleksi yang telah menggunakan sistem komputerisasi. Dalam penelitian ini mencakup 8 poin pernyataan; c). library as place, penilaian terhadap ketersediaan fasilitas dan kebersihan yang diberikan oleh perpustakaan agar pengguna merasa nyaman di perpustakaan, sehingga perpustakan dapat digunakan sebagai tempat berkegiatan bersama sepertti diskusi, belajar, dan sebagainya. Dalam penelitian ini mencakup 6 poin pernyataan.

Analisis dari ketiga dimensi didapat dengan menjumlahkan semua skor penilaian layanan yang diberikan/diterima pengguna, harapan minimum, dan harapan maksimum. Lalu dibagi jumlah poin pernyataan pada masing-masing dimensi, sehingga diketahui nilai ratarata layanan yang diberikan/diterima pengguna, nilai harapan minimum, dan nilai harapan maksimum. Nilai dari masing-masing dimensi yang telah dianalisa disajikan pada tabel berikut ini:

Tabel 2 Nilai Rata-Rata Dimensi Kualitas Layanan Perpustakaan STIE Ekuitas

\begin{tabular}{|c|c|c|c|c|c|}
\hline $\begin{array}{c}\text { Dimensi kualitas layanan } \\
\text { perpustakaan }\end{array}$ & $\begin{array}{c}\text { Harapan } \\
\text { Minimum }\end{array}$ & $\begin{array}{c}\text { Harapan } \\
\text { Maksimum }\end{array}$ & $\begin{array}{c}\text { Layanan yang } \\
\text { diberikan }\end{array}$ & AG & SG \\
\hline Affect of Service & 5,80 & 7,29 & 6,25 & 0,46 & $-1,04$ \\
\hline Information Control & 5,97 & 7,51 & 6,63 & 0,66 & $-0,88$ \\
\hline Library asPlace & 6,03 & 7,78 & 7,01 & 0,98 & $-0,77$ \\
\hline
\end{tabular}

Sumber : Hasil Pengolahan Data Penelitian, 2019 
Berdasarkan tabel diatas bahwa nilai kesenjangan dimensi kualitas layanan perpustakaan yang paling tinggi adalah pada dimensi Library as Place, dengan skor Adequacy Gap (AG) sebesar 0,98 dan skor Superiority Gap (SG) sebesar -0,77. Nilai AG berada dalam batas toleransi (zone of tolerance) yaitu sudah memenuhi harapan minimum pengguna, namun belum memenuhi harapan yang diinginkan pengguna. Nilai tersebut menggambarkan bahwa layanan perpustakaan pada dimensi ini cukup baik menurut pengguna yang artinya tempat dan ruangan perpustakaan sudah cukup baik untuk digunakan. Poin pernyataan tertinggi pada dimensi ini adalah pernyataan nomor 15 yang berarti ruangan sudah memberikan kenyamanan. Selanjutnya yang kedua adalah pada pernyataan nomor 17 yang berarti ruangan dapat digunakan untuk diskusi dan belajar bersama dengan baik. Dan yang ketiga adalah pada pernyataan nomor 20 yang berarti ruangan telah terjaga kebersihan dan kerapihannya. Sedangkan poin pernyataan terendah pada dimensi ini adalah pada pernyataan nomor 19 yang berarti suasana ruangan belum cukup kondusif bagi pengguna untuk berkunjung secara rutin. Ruangan perpustakaan selain dalam kondisi yang baik juga sebaiknya menampilkan suasana yang kondusif.

Berdasarkan Peraturan Pemerintah RI No. 24 tahun 2014 tentang pelakasanaan Undang-Undang No. 43 Tahun 2007 tentang Perpustakaan, pada pasal 22 ayat 4, disebutkan bahwa gedung perpustakaan paling sedikit memiliki ruang koleksi, ruang baca, dan ruang staf yang ditata secara efektif, efisien, dan estetik. Pada dimensi ini pengguna menilai fasilitas yang disediakan oleh Perpustakaan STIE Ekuitas Bandung masih belum kondusif, karena terlihat belum memenuhi fungsi yang baik atau semestinya. Sementara kebersihan gedung cukup baik, namun akan lebih baik lagi apabila pustakawan (staf perpustakaan) mengarahkan pengguna agar berpartisipasi untuk menjaga kebersihan perpustakaan. Selain itu, Perpustakaan STIE Ekuitas Bandung sebaiknya berupaya untuk memenuhi permintaan pengguna dengan merenovasi ruangan koleksi dan referensi, agar semua koleksi, baik yang lama hingga yang baru, dapat tersimpan dan tersusun dengan baik.

Nilai kesenjangan dimensi kualitas layanan yang berada di urutan berikutnya adalah Information Control, dengan skor Adequacy Gap (AG) sebesar 0,66 dan skor Superiority Gap (SG) sebesar -0,88. Nilai AG berada dalam batas toleransi (zone of tolerance) yaitu sudah memenuhi harapan minimum pengguna, namun belum memenuhi harapan yang diinginkan pengguna. Nilai tersebut menggambarkan bahwa layanan perpustakaan pada dimensi ini juga sudah cukup baik menurut pengguna. Artinya kemudahan mendapatkan informasi sudah cukup baik. Poin pernyataan tertinggi pada dimensi ini adalah pernyataan 
nomor 14 yang berarti telah tersedianya fasilitas internet bagi pengguna. Namun hal ini diharapkan diikuti dengan peningkatan kecepatan akses seiring dengan pertambahan jumlah pengunjung.

Telah dijelaskan berdasarkan Peraturan Pemerintah RI No. 24 tahun 2014 tentang pelakasanaan Undang-Undang No. 43 Tahun 2007 tentang Perpustakaan, pasal 20 ayat 3 bahwa akses informasi paling sedikit berupa parabot, peralatan, dan sarana temu kembali bahan perpustakaan dan informasi, yang dimaksud dengan "sarana akses informasi" adalah sarana pengguna untuk mengakses internet berupa komputer dan jaringan internet. Selanjutnya yang kedua adalah pernyataan nomor 11 yang berarti proses sirkulasi sudah berjalan baik. Dan yang ketiga adalah pernyataan nomor 7 yang berarti bahwa penataan dilakukan dengan cukup baik dan memudahkan pengguna untuk mencari koleksi, namun untuk memperlancar shelving/penataan dibutuhkan tambahan staf perpustakaan/pustakawan, karena jumlah pustakawan di Perpustakaan STIE Ekuitas Bandung dinilai masih kurang. Sedangkan poin pernyataan terendah pada dimensi ini adalah pernyataan nomor 10 yang berarti pengguna masih merasa kurang puas dengan koleksi yang tersedia, dan tentu saja hal ini harus diikuti dengan penambahan ruangan baru untuk dapat menampung penambahan koleksi.

Kebijakan pengembangan koleksi seperti dikutip dari buku Pedoman Penyelenggaraan Perpustakaan Penguruan Tinggi (2015) menyebutkan bahwa : Penambahan koleksi per tahun $2 \%$ dari total koleksi (judul) yang sudah ada, atau minimal 1 judul untuk 1 mata kuliah dipilih yang lebih besar. Pemilihan pustaka merupakan kegiatan awal dari pembinaan koleksi. Pembinaan koleksi harus direncanakan sebaik-baiknya agar layanan yang diberikan oleh perpustakaan benar-benar dapat memenuhi kebutuhan pemustaka. Langkah awal dari pengadaan koleksi adalah melakukan penelitian mengenai kebutuhan pemustaka. Untuk mengetahui kebutuhan pemustaka, informasi yang perlu dikumpulkan adalah jenis fakultas, program studi, jenjang studi, mata kuliah yang ditawarkan, penelitan yang dilaksanakan oleh sejumlah pengajar dan mahasiswa. Penelitian ini dilakukan secara periodik, mengingat kebutuhan masyarakat perguruan tinggi selalu berubah. Dalam pemilihan bahan perpustakaan hendaknya memperhatikan juga kebijakan peraturan berlaku tentang buku-buku atau bahan pustaka lainnya yang dilarang beredar di masyarakat. Adapun yang dapat turut menyeleksi diantaranya dosen, spesialis subjek, peneliti dan mahasiswa.

Nilai kesenjangan dimensi kualitas layanan yang paling rendah adalah Affect of Service, dengan skor Adequacy Gap (AG) sebesar 0,46 dan skor Superiority Gap (SG) sebesar -1,04. Nilai AG berada dalam batas toleransi (zone of tolerance) yaitu sudah 
memenuhi harapan minimum pengguna, namun belum memenuhi harapan yang diinginkan pengguna. Nilai tersebut menggambarkan bahwa layanan perpustakaan pada dimensi ini memang cukup baik menurut pengguna. Artinya sikap dan kemampuan pustakawan dalam melayani pengguna sudah cukup baik namun dengan skor yang paling kecil diantara dimensi lainnya. Poin pernyataan tertinggi pada dimensi ini adalah pernyataan nomor 2 yang berarti pustakawan melayani dengan cukup sopan dan ramah. Selanjutnya yang kedua adalah pernyataan nomor 1 yang berarti pustakawan memiliki pengetahuan dan wawasan yang cukup. Dan yang ketiga adalah pernyataan nomor 4 yang berarti pustakawan cukup membantu pengguna untuk mencari informasi. Sedangkan poin pernyataan terendah pada dimensi ini adalah pernyataan nomor 6 yang berarti pustakawan belum cukup tanggap dalam membantu kesulitan pengguna. Sebaiknya pustakawan memberikan layanan kepada pengguna dengan waktu durasi yang lebih efisien dan prima, karena memberikan pelayanan yang efisien dan prima adalah faktor penting dalam pencapaian kepuasaan pengguna.

Hermawan dan Zen (2006) menyatakan bahwa, pertama, memberikan layana prima, artinya pelayanan kepada masyarakat harus dilakukan secara cepat, tepat, mudah, murah tertib, dan tuntas sesuai dengan prosedur yang berlaku sehingga dapat memuaskan masyarakat pengguna. Kedua, pelayanan harus dilakukan dengan senyum, artinya pustakawan memberikan pelayanan harus menggunakan prinsip 4 (empat) S yaitu: senyum, salam, sopan, dan santun sehingga pelayanan berlangsung dalam suasana ramah dan menyenangkan. Diharapkan dengan pelayanan itu akan terwujud pelayanan yang memuaskan bagi para pengguna perpustakaan. Dan ketiga, layanan kepada masyarakat harus dilakukan secara tulus. Berarti bahwa pustakawan dalam melaksanakan pelayanannya, tidak boleh meminta imbalan dalam bentuk apapun dari masyarakat pengguna perpustakaan. Diharapkan dengan pelayanan tersebut akan menumbuhkan rasa simpati dan rasa ingin kembali memanfaatkan fasilitas-fasilitas yang ada di perpustakaan.

Kualitas layanan perpustakaan adalah faktor yang sangat penting untuk mencapai kepuasan pengguna, semakin baik kualitas layanan yang diberikan maka semakin puaslah pengguna. Kualitas layanan harus berpusat pada pemenuhan kebutuhan informasi pengguna. Jika kualitas layanan yang diberikan sangat buruk atau lebih rendah, maka pengguna akan kecewa atau tidak puas terhadap layanan perpustakaan.

Analisis butir pernyataan pada penelitian ini adalah analisis yang dilakukan terhadap 20 poin pernyataan sesuai dengan kuesioner. Nilai yang didapat yakni dari layanan yang diberikan, harapan minimum, dan harapan maksimum. Ketiga poin penilaian tersebut dijumlahkan lalu dibagi dengan jumlah responden sehingga diketahui nilai rata-rata dari poin 
layanan yang diberikan, harapan minimum, dan harapan maksimum.

Dari hasil analisis data diketahui bahwa nilai kesenjangan Adequacy Gap (AG) dari semua poin pernyataan menghasilkan nilai rata-rata skor yang positif. Dari seluruh poin pernyataan yang mendapatkan skor kesenjangan positif merupakan nilai rata-rata layanan yang diberikan lebih tinggi dari pada nilai rata-rata harapan minimum. Artinya bahwa layanan sudah dapat memenuhi harapan pengguna, atau pengguna cukup puas dengan layanan perpustakaan yang diterima. Untuk lebih jelasnya dapat dilihat dalam tabel dibawah ini poin pernyataan yang mendapatkan nilai Adequacy Gap (AG) positif pada tiap butir pernyataan penelitian.

Tabel 3 Analisis Butir Pernyataan pada setiap Dimensi

\begin{tabular}{|c|c|c|}
\hline $\begin{array}{l}\text { Sub Variabel (Dimensi } \\
\text { LibQual+TM) }\end{array}$ & Pernyataan & Skor \\
\hline \multirow{6}{*}{$\begin{array}{l}\text { Kemampuan dan Sikap staf } \\
\text { dalam melayani pengguna } \\
\text { (Affect of Service) }\end{array}$} & $\begin{array}{l}\text { Pengguna menyatakan bahwa } \\
\text { pustakawan memiliki pengetahuan dalam } \\
\text { bidang serta memiliki wawasan yang } \\
\text { luas. }\end{array}$ & 0,45 \\
\hline & $\begin{array}{l}\text { Pengguna menyatakan bahwa } \\
\text { pustakawan melayani saya dengan sopan } \\
\text { dan ramah. }\end{array}$ & 0,97 \\
\hline & $\begin{array}{l}\text { Pengguna menyatakan bahwa } \\
\text { pustakawan selalu memberikan solusi } \\
\text { atas setiap masalahnya yang ditemui. }\end{array}$ & 0,38 \\
\hline & $\begin{array}{l}\text { Pengguna menyatakan bahwa } \\
\text { pustakawan memberikan bimbingan } \\
\text { kepadanya untuk mencari informasi yang } \\
\text { di cari. }\end{array}$ & 0,49 \\
\hline & $\begin{array}{l}\text { Pengguna menyatakan bahwa } \\
\text { pustakawan memiliki rasa peduli dan } \\
\text { selalu menjadi pendengar yang baik atas } \\
\text { keluhannya saat di perpustakaan. }\end{array}$ & 0,25 \\
\hline & $\begin{array}{l}\text { Pengguna menyatakan bahwa } \\
\text { pustakawan selalu sigap dan tanggap } \\
\text { untuk membantu kesulitannya yang } \\
\text { ditemui di perpustakaan. }\end{array}$ & 0,18 \\
\hline \multirow{3}{*}{$\begin{array}{l}\text { Ketersediaan informasi dan } \\
\text { kemudahan akses informasi } \\
\quad \text { (Information Control) }\end{array}$} & $\begin{array}{l}\text { Pengguna menyatakan bahwa penataan } \\
\text { koleksi perpustakaan (buku, ilmiah, } \\
\text { jurnal, skripsi/ta, dsb.) memudahkan saya } \\
\text { dalam menemukan kembali. }\end{array}$ & 0,71 \\
\hline & $\begin{array}{l}\text { Pengguna menyatakan bahwa koleksi } \\
\text { perpustakaan (buku, ilmiah, jurnal, } \\
\text { skripsi/ta, dsb.) yang memadai sesuai } \\
\text { dengan kebutuhannya. }\end{array}$ & 0,56 \\
\hline & $\begin{array}{l}\text { Pengguna menyatakan bahwa } \\
\text { ia merasa mudah dalam menggunakan } \\
\text { layanan di perpustakaan. }\end{array}$ & 0,64 \\
\hline
\end{tabular}




\begin{tabular}{|c|c|c|}
\hline & $\begin{array}{l}\text { Pengguna menyatakan bahwa isi koleksi } \\
\text { perpustakaan (buku, ilmiah, jurnal, } \\
\text { skripsi/ta, dsb.) selalu up to date. }\end{array}$ & 0,32 \\
\hline & $\begin{array}{l}\text { Pengguna menyatakan bahwa automasi } \\
\text { perpustakaan membuat waktu (timeless) } \\
\text { layanan sirkulasi menjadi lebih cepat. }\end{array}$ & 0,8 \\
\hline & $\begin{array}{l}\text { Pengguna menyatakan dengan } \\
\text { adanya katalog online/OPAC dapat } \\
\text { memudahkannya dalam menelusur } \\
\text { informasi di perpustakaan. }\end{array}$ & 0,67 \\
\hline & $\begin{array}{l}\text { Pengguna menyatakan bahwa adanya } \\
\text { website perpustakaan (Repository) } \\
\text { memudahkan saya dalam menemukan } \\
\text { koleksi di perpustakaan. }\end{array}$ & 0,62 \\
\hline & $\begin{array}{l}\text { Pengguna menyatakan bahwa adanya } \\
\text { fasilitas internet yang dapat } \\
\text { memudahkannya dalam mencari } \\
\text { informasi kapan saja. }\end{array}$ & 0,95 \\
\hline \multirow{6}{*}{$\begin{array}{l}\text { Ketersediaan fasilitas } \\
\text { perpustakaan (Library as } \\
\text { Place) }\end{array}$} & $\begin{array}{l}\text { Pengguna menyatakan bahwa } \\
\text { ruangan perpustakaan memberikan } \\
\text { kenyamanan untuknya. }\end{array}$ & 1,18 \\
\hline & $\begin{array}{l}\text { Pengguna menyatakan bahwa fasilitas } \\
\text { gedung dan peralatan fisik (rak, meja } \\
\text { baca, kursi, dsb.) di perpustakaan sangat } \\
\text { memadai. }\end{array}$ & 0,95 \\
\hline & $\begin{array}{l}\text { Pengguna menyatakan bahwa } \\
\text { perpustakaan terbuka untuk aktivitas } \\
\text { diskusi/belajar bersama. }\end{array}$ & 1,20 \\
\hline & $\begin{array}{l}\text { Pengguna menyatakan bahwa } \\
\text { ruangan perpustakaan memberikan } \\
\text { inspirasi saya untuk membaca dan belajar. }\end{array}$ & 0,75 \\
\hline & $\begin{array}{l}\text { Pengguna menyatakan bahwa } \\
\text { suasana perpustakaan mengundangnya } \\
\text { untuk selalu berkunjung. }\end{array}$ & 0,64 \\
\hline & $\begin{array}{l}\text { Pengguna menyatakan bahwa ruangan } \\
\text { perpustakaan yang bersih dan rapih } \\
\text { membuatnya betah. }\end{array}$ & 1,16 \\
\hline
\end{tabular}

Sumber : Hasil Pengolahan Data Penelitian, 2019

Tabel diatas menunjukkan bahwa pernyataan dengan skor rata-rata AG paling tinggi secara umum ada pada pada dimensi Library as Place dengan skor 1,20. Sedangkan pernyatan paling rendah ada pada pada dimensi Affect of Service dengan skor 0,18. Kesenjangan pada seluruh pernyataan tidak ada satupun yang mempeloreh kesenjangan AG dengan skor negatif. Artinya bahwa pengguna cukup puas terhadap layanan yang diterima atau diberikan oleh perpustakaan. Layanan dapat dikatakan sudah memenuhi harapan minimum pengguna.

Pada dimensi Affect of Service, yaitu kemampuan, sikap dan kesiapan staf perpustakaan dalam melayani pengguna dinilai cukup berkualitas. Hasil penelitian 
menunjukkan bahwa nilai rata- rata layanan yang diberikan/diterima pengguna ada diantara nilai rata-rata harapan minimum dan harapan yang diinginkan. Nilai kesenjangan AG bernilai positif dan kesenjangan SG bernilai negatif. Nilai kesenjangan tersebut berarti bahwa pengguna cukup puas namun layanan perpustakaan pada dimensi ini masih belum memenuhi harapan yang diinginkan pengguna. Dari 6 (enam) poin pernyataan yang digunakan, semua nilai kesenjangan AG bernilai positif dan semua nilai kesenjangan SG bernilai negatif. Kelebihan pada dimensi ini adalah sikap dan kemampuan pustakawan dalam melayani pengguna sudah cukup ramah dan sopan. Kekurangan pada dimensi ini adalah pustakawan/staf perpustakaan belum cukup tanggap dalam membantu kesulitan pengguna.

Pada dimensi Information Control, yaitu kelengkapan/ketersediaan koleksi, jam waktu layanan perpustakaan, dan akses informasi bedasarkan lama waktu tunggu sudah dinilai cukup berkualitas. Hasil penelitian menunjukkan bahwa nilai rata- rata pengguna untuk layanan yang diberikan/diterima pengguna ada diantara nilai rata-rata harapan minimum dan harapan yang diinginkan. Hasil kesenjangan AG bernilai positif dan kesenjangan SG bernilai negatif. Hal tersebut berarti bahwa pengguna juga cukup puas namun layanan perpustakaan pada dimensi ini masih belum memenuhi harapan yang diinginkan pengguna. Dari 8 (delapan) poin pernyataan, semua nilai kesenjangan AG bernilai positif dan semua nilai kesenjangan SG bernilai negatif. Kelebihan pada dimensi ini adalah tersedianya fasilitas internet bagi pengguna. Sedangkan kekurangan pada dimensi ini adalah pengguna masih merasa kurang puas dengan koleksi yang tersedia. Perpustakaan diharapkan dapat meningkatkan pengadaan dan penyediaan koleksi yang baru.

Pada dimensi Library as Place, yaitu kemampuan perpustakaan dalam menyediakan dan mempersiapkan ruang layanan sebagai simbol tempat dinilai sudah cukup berkualitas. Hasil penelitian menunjukkan bahwa dari nilai rata-rata persepsi berada diantara nilai ratarata harapan minimum dan harapan yang diinginkan. Nilai kesenjangan AG dan nilai SG pada dimensi ini menunjukkan bahwa pengguna cukup puas namun masih belum memenuhi harapan yang diinginkan pengguna. Dari 6 (enam) poin pernyataan yang digunakan, semua nilai kesenjangan AG bernilai positif dan semua nilai kesenjangan SG bernilai negatif. Kelebihan pada dimensi ini adalah bahwa perpustakaan selalu terbuka sebagai tempat untuk belajar, sedangkan kekurangan pada dimensi ini adalah suasana perpustakaan yang belum membuat mereka selalu ingin mengunjunginya. 


\section{E. KESIMPULAN DAN SARAN}

Berdasarkan hasil analisis diperoleh kesimpulan bahwa secara umum kualitas layanan Perpustakaan STIE Ekuitas Bandung telah memenuhi harapan minimum pengguna dengan nilai rata-rata layanan yang diberikan (persepsi) lebih tinggi dari nilai harapan minimum, namun masih lebih rendah dari nilai harapan sesungguhnya. Nilai kesenjangan AG (Adequacy Gap) positif, namun memiliki nilai kesenjangan SG (Superiority Gap) negatif. Artinya bahwa secara umum perpustakaan dinilai belum mampu memenuhi harapan sesungguhnya dari pengguna. Persepsi pengguna berada pada area zone of tolerance atau area toleransi, yakni bahwa kualitas layanan di Perpustakaan STIE Ekuitas Bandung masih ada pada kategori cukup baik dan pengguna menilai cukup puas.

Saran yang kiranya perlu disampaikan yakni bahwa perpustakaan ini diharapkan dapat terus meningkatkan pelayanan di masa yang akan datang. Diperlukan peningkatan kemampuan dan keterampilan (kompetensi) bagi staf perpustakaan baik melalui jalur pendidikan formal maupun pelatihan dalam bidang perpustakaan baik yang diselenggarakan oleh pihak lain maupun internal kampus. Diharapkan staf perpustakaan juga dapat mengembangkan pengetahuan dan wawasan dengan mengikuti seminar-seminar tentang kepustakawanan serta aktif mengikuti perkembangan dunia perpustakaan dan kepustakawanan melalui berbagai media pembelajaran. Alangkah baik jika dilakukan pelatihan pelayanan bagi staf perpustakaan sehingga dapat lebih memahami konsep dan praktik pelayanan prima. Sebaiknya juga dilakukan penambahan koleksi yang sesuai dengan kebutuhan pengguna dan perkembangan keilmuan dalam bidang yang diselenggarakan dalam pendidikan di STIE Ekuitas.

Didalam Peraturan Pemerintah RI Nomor 24 Tahun 2014 tentang Pelaksanaan Undang-Undang Nomor 43 Tahun 2007 tentang perpustakaan, pada bagian IV tentang standar nasional perpustakaan, pasal 13 ayat (3) disebutkan bahwa jumlah koleksi pada setiap perpustakaan perguruan tinggi paling sedikit 2.500 judul. Selanjutnya pada pasal 14 ayat (2) disebutkan bahwa kebijakan pengembangan koleksi harus menambah jumlah koleksi perpustakaan per tahun sesuai dengan kebutuhan pengguna. Sebaiknya ada penambahan ruangan maupun rak buku untuk mendukung penambahan koleksi dan berbagai bahan referensi. Sebaiknya ada penambahan fasilitas stop kontak listrik untuk mengisi daya alat elektronik bagi pengguna yang menggunakan laptop untuk menulis maupun gadget untuk mengakses internet di perpustakaan. Kiranya kecepatan internet yang sudah ada agar ditingkatkan untuk mengantisipasi penambahan jumlah pengunjung. Diharapkan Perpustakaan STIE Ekuitas Bandung terus mengembangkan layanan OPAC sebagai sarana 
telusur informasi secara online. Juga diharapkan dapat meng-update konten dan tampilan website agar dapat menjadi sarana komunikasi dan informasi yang lebih baik.

\section{DAFTAR PUSTAKA}

Aliza, Destia Nur \& Ardoni. (2017). Penggunaan Metodel LibQUAL ${ }^{+T M}$ Untuk Mengukur Kualitas Layanan di UPT Perpustakaan UNP. Jurnal Informasi Perpustakaan dan Kearsipan. 5 (1) : 210-219.

Fatmawati, E. (2011). Kajian Teoritis Mengenai Metode LibQUAL ${ }^{+T M}$ untuk Mengevaluasi Kualitas Layanan Perpustakaan. Jurnal Ilmiah Kepustakawanan "Libraria", 1(1), 45-80.

Fatmawati, E. (2013). Matabaru Penelitian Perpustakaan : dari SERVQUAL ke LibQUAL+TM. Jakarta : Sagung Seto.

Hermawan, R. \& Zen, Z. (2006). Etika Kepustakawanan : Suatu Pendekatan Terhadap Profesi dan Kode Etik Pustakawan Indonesia. Jakarta : Sagung Seto.

Nurvia, Era \& Angraini. (2016). Pengukuran Kualitas Layanan Digital Library Terhadap Kepuasan Pengguna Menggunakan Metode Libqul. Jurnal Rekayasa dan Manajemen Informasi. 2 (2) : 30-37

Perpustakaan Nasional RI. (2014). Peraturan Pemerintah Nomor 24 Tahun 2014 Pelaksanaan Undang-Undang Nomor 43 Tahun 2007 Tentang Perpustakaan. Diakses pada tanggal 27 Juni 2019 dari https://www.hukumonline.com/pusatdata/detail/lt536b23ab14888/\#

Perpustakaan Nasional RI. (2015). Pedoman Penyelenggaraan Perpustakaan Penguruan Tinggi. Edisi ke-1 Cetakan ke-1. Jakarta : Perpusnas RI.

Sutarno, N. S. (2005). Tanggung Jawab Perpustakaan Dalam Mengembangkan Masyarakat Informasi. Jakarta : Panta Rei.

Tjiptono, F. (2008). Strategi Pemasaran. Edisi 3. Yogyakarta : Penerbit Andi.

Woodward, J. A. (2009). Creating The Customer Driven Academic Library. America : American Library Association.

Wijaya, Toni. (2018). Manajemen Kualitas Jasa : Desain Servqual, QFD, dan Kano. Jakarta : PT. Indeks

Yulianti \& Rohman, Asep Saeful. (2016). Pengaruh Kualitas Layanan Terhadap Kepuasan Pengguna di Perpustakaan Fakultas Ilmu Komunikasi. Journal of Library and Information Science "Edulib”, 6 (2) : 113-128. 
